\title{
Оцінювання впливу занять з карате на показники фізичного здоров'я у дітей 8-10 років
}

\author{
Удк 615.825.4
}

В. Ф. Гагара, В. В. Логвиненко

Запорізький національний технічний університет, Запоріжжя, Україна

Резюме. Мета: визначення ефективності впливу занять з карате (WKF) на підвищення рівня фізичного здоров'я дітей віком 8-10 років. Методи: аналіз літературних джерел; дослідження морфофункціонального стану організму, фізичної рекреації; педагогічного експерименту; математичної статистики. Результати. Майже всі обстежені діти мали переважно нижчий за середній рівень фізичного здоров'я, а також порушення постави у фронтальній і сагітальній площинах. Найпоширенішими порушеннями в обстежуваній групі виявились сутулуватість і сколіотична постава. Всі виявлені порушення є функціональними (нефіксованими) і підлягають корекції. В результаті шестимісячного тренувального циклу з регулярними тренуваннями тричі на тиждень достовірно підвищився рівень фізичного здоров'я, покращилися показники постави як у фронтальній, так і в сагітальній площині (загальні результати обстеження за картою рейтингу постави та плечовий показник), суттєво покращились результати тестів на гнучкість. Висновки. Використання засобів карате, а саме розділів програми «кихон» (виконання рухів і переміщень у стійках) і «ката», сприяє підвищенню рівня фізичного здоров'я, дозволяє дітям сформувати уявлення про правильну поставу і зменшити ризик розвитку їі порушень, є ефективним засобом у коригуванні нефіксованих порушень постави у дітей. Ключові слова: діти, фізичне здоров'я, підвищення рівня, заняття з карате, ефективність.

Резюме. Цель: определение эффективности влияния занятий по каратэ (WKF) на повышение уровня физического здоровья детей 8-10 лет. Методы: анализ литературных источников; исследования морфофункционального состояния организма, физической рекреации; педагогического эксперимента; математической статистики. Результаты. Почти все обследованные дети имели уровень физического здоровья преимущественно ниже среднего, а также нарушения осанки во фронтальной и сагиттальной плоскостях. Наиболее распространенными нарушениями в обследуемой группе оказались сутуловатость и сколиотическая осанка. Все выявленные нарушения являются функциональными (нефиксированными) и подлежат коррекции. В результате шестимесячного тренировочного цикла с регулярными тренировками трижды в неделю достоверно повысился уровень физического здоровья, улучшились показатели осанки как во фронтальной, так и в сагиттальной плоскости (общие результаты обследования по карте рейтинга осанки и плечевой показатель), существенно улучшились результаты тестов на гибкость. Выводы. Использование средств каратэ, а именно разделов программы «кихон» (выполнение движений и перемещений в стойках) и «ката», способствует повышению уровня физического здоровья, позволяет детям сформировать представление о правильной осанке и свести к минимуму риск развития ее нарушений, является эффективным способом в коррекции нефиксированных нарушений осанки у детей.

Ключевые слова: дети, физическое здоровье, повышение уровня, занятия по каратэ, эффективность.

Abstract. Objective: to determine the effectiveness of karate (WKF) sessions on the improvement of physical health of children aged 8-10 years. Methods: analysis of literary sources; studying the bodt morphofunctional state, physical recreation; pedagogical experiment; mathematical statistics. Results. Almost all examined children had a predominantly lower than average level of physical health, as well as abnormal posture in the frontal and sagittal planes. The most common abnormalities in the study group were stiffness and scoliostic posture. All detected disorders are functional (non-fixed) and subject to correction. As a result of a six-month training cycle with regular training three times a week, the level of physical health has significantly increased, posture indices have improved both in the frontal and sagittal plane (general results of the survey according to posture ranking map and the shoulder index), the results of flexibility tests have improved significantly. 
Conclusions. The use of karate means, namely sections of the program «kihon» (reduction of movement and movement in stances) and «kata», promotes the increase of the physical health, allows children to form an idea about the correct posture and reduce the risk of the development of its disorders, and is an effective means in correction of non-fixed posture disorders in children.

Keywords: children, physical health, level increase, karate sessions, efficiency.

Вступ. Складні соціально-економічні проблеми сучасного українського суспільства разом із морально-психологічною кризою у свідомості широких верств населення призвели до поширення негативних тенденцій у ставленні людей до свого здоров'я. Молоді люди віддають перевагу пасивним фоомам проведення дозвілля, менше половини юнаків і дівчат призвичаєні до фрізичної культури та оздоровлення, спостерігається тенденція їх раннього залучення до таких шкідливих звичок, як куріння, вживання алкоголю та наркотичних речовин (поширеність тютюнопаління серед молоді України $є$ однією з найвищих у Європі) [1].

Здоровий стан людини об'єктивно визначається за сукупністю антропометричних, клінічних, фрізіологічних і біохімічних показників. Усі ці показники певною мірою залежать від спадковості, віку, статі, умов виховання, кліматичних і географрічних умов життя. Ні духовні, ні душевні аспекти здоров'я не здатні компенсувати тяжких захворювань - інфаркту міокарда, раку або цукрового діабету. Ці стани обмежують соціальну активність індивіда, звужуючи межі його діяльності. Навіть практично здорові люди, володіючи різним рівнем соматичного здоров'я, мають різну профресійну придатність.

Таким чином, кількісна оцінка соматичного здоров'я - критерій, який може бути використаний для діагностики та оцінки зміцнення здоров'я. Елементами (показниками) здоров'я можуть бути кількісно охарактеризовані п'ять ознак:

- рівень і гармонійність фрізичного розвитку;

- функціональний стан організму;

- рівень імунного захисту і неспецисрічної резистентності;

- наявність будь-якого захворювання або дефекту розвитку;

- рівень морально-вольових цінностей і мотиваційних установок [2].

Під безпечним рівнем фрізичного (соматичного) здоров'я розуміють кількісно визначений резерв здоров'я, який перешкоджає фрормуванню ендогенних факторів ризику розвитку захворювань. На думку В. Клапчука та В. Самошкіна, фрізичне (соматичне) здоров'я припускає досить високий рівень фрізичної підготовленості, фрізичного розвитку і працездатності [6].

Здебільшого процес становлення здоров'я справедливо пов'язують 3 розвитком витривалості. Це обумовлено тим, що саме витривалість забезпечує різнобічну адаптацію внутрішніх органів, розширення резервів серцево-судинної $\mathrm{i}$ дихальної систем, забезпечуючи постачання тканин киснем. Тому за ступенем розвитку витривалості можна робити висновки про рівень фрізичного (соматичного, або тілесного) здоров'я. Його еквівалентом $\epsilon$ фрізичний стан людини $[7,8]$.

Фізичне здоров'я лежить в основі реалізації біологічних функцій - збереження особи та продовження роду. Фізичне здоров'я зумовлює високий рівень фрізичного розвитку, фрізичної підготовленості та працездатності. Основними показниками фрізичного здоров'я $є$ : рівень та гармонійність фрізичного розвитку, функціональний стан організму (його резервні можливості), рівень імунного захисту і неспецифрічної резистентності, наявність захворювання чи дефекту розвитку.

Статистичні дані, що характеризують стан здоров'я дітей, їхню фрізичну підготовку, свідчать про наявність тенденції до погіршення цих показників упродовж останніх 10 років [15].

У наукових дослідженнях відзначено, що рівень фрізичної підготовленості учнів, їхнього здоров'я, працездатності знижується $[11,14]$, фрізичний стан нації перетнув критичну межу й щороку погіршується. Спеціалісти свідчать, що з тисячі новонароджених 25 мають серйозні вади, що загрожують їхньому нормальному розвитку та життєдіяльності.

Дослідники акцентують увагу на тому, що $90 \%$ дітей і студентів нашої країни мають відхилення в стані здоров'я, 50 \% характеризуються незадовільним станом фрізичної підготовленості. Дослідження В. Шаповалова показує, що в Україні виявлено 1,4 \% школярів з високим рівнем фрізичного здоров'я, з вищим за середній $-10,1 \%$, середнім - $30 \%$, нижчим за середній - 30,6 \%, низьким - 21,9\% дітей. Такі дані дають підставу стверджувати, що більше половини учнів мають низький і нижчий за середній рівень фрізичного здоров'я [14]. 
Малоефективна організація й недостатньо продумана методика викладання фрізичного виховання в школі призвели до того, що $15 \%$ школярів перших класів уже мають відхилення в стані здоров'я. У багатьох випадках потенційні можливості, закладені в дитячому організмі, залишаються не використаними. Тому в комплексі фракторів, які впливають на фоомування здоров'я школярів, одне з важливих місць займає рухова активність, заняття фрізичною культурою і спортом. Дітей молодшого шкільного віку без відхилень у фізичному й психічному розвитку дуже мало $[11,17]$.

Пріоритетне місце в структурі дитячої патології займають порушення опорно-рухового апарату (ОРА), значну частину яких становлять порушення постави. Різні фооми порушень постави мають 40-71\% дітей шкільного віку.

Виявлення цих порушень ускладнюється тим, що ранні ознаки функціональних дефектів постави майже непомітні, і тому занепокоєння викликають уже суттєві, явно виражені структурні десрормації хребтового стовпа [16].

Корекція дефектів постави вимагає тривалих цілеспрямованих занять. Під корекцією постави слід розуміти профрілактичні та лікувальні заходи, спрямовані на усунення іï вад [16]. Аналіз різних класифрікацій засобів формування та корекції постави дозволяє об'єднати їх у три групи: вправи для вдосконалення розвитку рухових якостей 3 метою зміцнення м'язового корсета; спеціальні вправи для формування правильної постави; коригувальні вправи [5].

Загальне зміцнення здоров'я тісно пов'язане з підвищенням фізичної працездатності організму, яка проявляється у збільшенні сили, підвищенні швидкості і витривалості. Відтак, заняття фрізичними вправами сприяють вирішенню низки оздоровчих завдань. Під час виконання фрізичних вправ відбуваються глибокі зміни в діяльності м'язів, центральної нервової системи та всіх внутрішніх органів, що сприяє поліпшенню здоров'я і фрізичного розвитку дітей.

Дитина займається карате в провітрюваній залі в зручному кімоно і босоніж. При цьому відбувається загартовування організму через повітряне середовище і безпосередній контакт ніг із татамі, що, імовірно, дозволяє організму набути опірність до застудних та інфекційних хвороб (ГРЗ, бронхіт, ангіна, кір, краснуха, грип та ін.).

Формуванню захисних сил організму сприяє також застосування великої кількості дихальних вправ [12], що $є$ характерними для кожного тренувального заняття 3 карате.

Ще одним важливим оздоровчим завданням, яке успішно вирішується засобами фрізичного виховання, $\epsilon$ гармонійне зміцнення опорно-рухового апарату i формування правильної постави (тобто утримання раціональної пози під час усіх видів діяльності).

3 ранніх років у дитини необхідно створювати уявлення про правильну поставу. Так, тренування за програмою карате починаються і закінчуються ритуалом. При цьому дитина перебуває у статичній позі «сейза» сидячи на колінах з прямою спиною, що дає можливість запам'ятати правильне положення хребта. Крім того, формуванню правильної постави допомагає цілий розділ програми «кихон» (виконання рухів і переміщень у стійках) [13].

Активна рухова діяльність дитини під час заняття сприяє зміцненню дихальної [7], серцевосудинної систем, системи крові $[4,9,10]$. Тому заняття карате чинять позитивний вплив на функціональний стан та адаптаційні можливості органів і систем організму. Тісно пов'язаними з оздоровчими $€$ завдання, спрямовані на виховання фрізичних якостей (координаційних, швидкісних, силових і витривалості).

Зв'язок роботи 3 важливими науковими програмами або практичними завданнями. Дослідження присвячено важливій проблемі, яка пов'язана зі зміцненням та підвищенням рівня фрізичного здоров'я дітей та підлітків України.

Мета дослідження - визначенні загальних особливостей негативних змін показників фрізичного здоров'я у дітей 8-10 років та оцінювання ефективності впливу занять $з$ карате (WKF) на підвищення їх рівня.

Методи i організація дослідження. Дослідження проводилося на базі запорізької обласної фредерації карате (клуб «Прайд») м. Запоріжжя. У дослідженні брала участь група з 12 каратистів-початківців віком 8-10 років. Всі хлопці мали довідку про стан здоров'я і були допущені лікарем до тренувань.

Морфрофункціональний стан організму хлопчиків досліджуваної групи до та після проведення занять $з$ карате визначався за допомогою карти рейтингу постави В. В. Клапчука, а також таких показників, як тест на гнучкість хребта, обчислення плечового показника, експрес-оцінювання рівня фрізичного здоров'я дітей за Г. Л. Апанасенко, проби Руф'є, життєвий та силовий індекси, індекс Робінсона.

Тренувальний цикл тривав шість місяців. Тренування проводили тричі на тиждень за програмою початкової підготовки.

Заняття мали переважно ігровий та змагальний характер, що дозволяло підтримувати позитивний емоційний фон та успішно боротися 3 


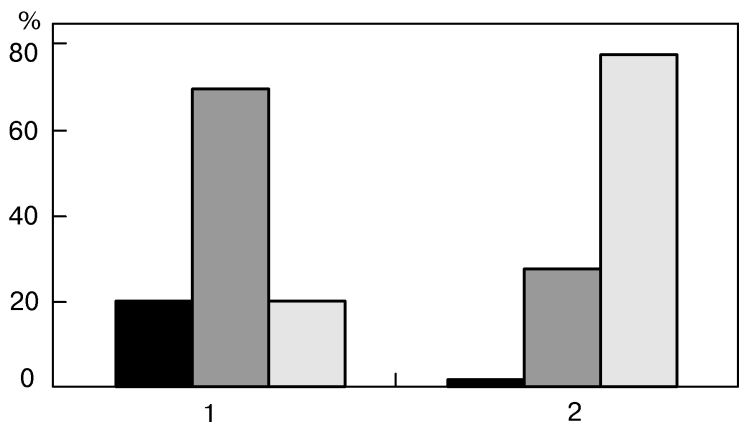

Рисунок 1 - Динаміка плечового показника (відсоток від загальної кількості досліджених):

1 - на початку дослідження, 2 - наприкінці дослідження; - сутулість; - сутулуватість; $\square$ - норма

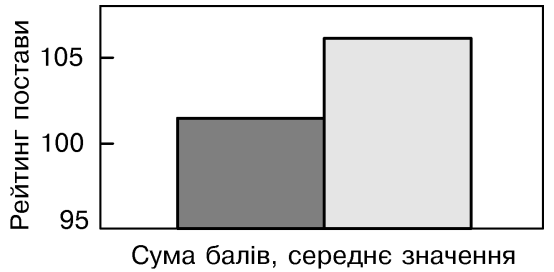

Рисунок 2 - Загальні результати обстеження за картою рейтингу постави:

$\square-$ початковий результат; $\square-$ кінцевий результат

монотонністю під час вивчення технічних прийомів карате. Перед початком вивчення комплексу прийомів за системою карате виконували спеціальний комплекс вправ. Це вправи для витривалості, гнучкості та зміцнення суглобів і вестибулярного апарату, використовувалась традиційна для карате динамічна розминка, вправи $з$ елементами йоги сидячи та лежачи, дихальні вправи.

Орієнтовний перелік вправ такий: динамічна розминка, розминка швидкісна, розминка сидячи і лежачи, техніко-тактична підготовка $[3,7]$.

Всі дослідження проводилися відповідно до принципів біоетики.

Результати дослідження та їх обговорення. В результаті проведених досліджень встановлено, що за тестом на гнучкість (загальна амплітуда рухів тулуба) до початку тренувань нормальний результат поворотів тулуба мали 33,3 \% хлопців, а після циклу тренувань цей показник збільшився до $58,34 \%$. На початку тренувального циклу показник рухів у фрронтальній площині відповідав нормі у 24,99 \% дітей, а наприкінці - у 75,01\%. Нормальний результат розгинання тулуба на початку тренувального циклу мали 24,99\%, а після тренувань - 75,01 \% учнів. Показники згинання тулуба, які відповідали нормі, на початку дослідження мали 33,3 \% обстежуваних, а після тренувань $-91,67 \%$.
Динаміка плечового показника відображена на рисунку 1.

Середні результати обстежуваної групи за картою рейтингу постави достовірно змінилися з 99,92 \pm 1,032 бала на початку дослідження до $105,00 \pm$ 0,94 бала після тренувального циклу (рис. 2).

Під час експрес-оцінювання рівня фрізичного здоров'я за Г. Л. Апанасенко було отримано такі результати: на початку тренувань середній показник життєвого індексу мали 50 \% дітей, а після тренувань кількість результатів, вищих за середній рівень, зросла з 8,33 до 41,66 \%.

На початку дослідження силовий індекс, нижчий від середнього рівня, відзначали у 83,3 \% дітей, середній - у 16,7, а наприкінці дослідження $50 \%$ результатів цього показника були вищими від середнього рівня.

За показником індексу Робінсона на початку дослідження реєстрували середні та нижчі за середні результати, тоді як наприкінці тренувань переважали середні та вищі за середні показники.

Первинне визначення індексу Руф'є показало середній рівень за цим показником у $100 \%$ дітей, а наприкінці дослідження 41,33 \% з них мали рівень, вищий за середній.

Таким чином, загальна сума балів за усіма показниками рівня фрізичного здоров'я свідчить про те, що на початку дослідження низький рівень мали 16,7 \% дітей, нижчий за середній $50 \%$, середній - 33,3\%. Після закінчення тренувального циклу рівень, нижчий за середній, мали 8,3 \% хлопців, середній - 41,67, вищий за середній - 16,7, високий - 33,3 \%. Рівень фрізичного здоров'я дітей наприкінці тренувального циклу достовірно підвищився.

\section{Висновки.}

Проведене дослідження показало, що майже всі обстежені каратисти-початківці мали переважно нижчий за середній рівень фрізичного здоров'я, а також порушення постави у фронтальній і сагітальній площинах. Найпоширенішими порушеннями в досліджуваній групі були сутулуватість i сколіотична постава. Всі виявлені порушення $€$ функціональними (нефріксованими) і підлягають корекції.

В результаті шестимісячного тренувального циклу з регулярними тренуваннями тричі на тиждень достовірно підвищився рівень фрізичного здоров'я, показники постави як у фронтальній, так і у сагітальній площині (загальні результати обстеження за картою рейтингу постави та плечовий показник), суттєво покращились результати тестів на гнучкість. 
Отже використання засобів карате, а саме розділів програми «кихон» (виконання рухів і переміщень в стійках) i «ката», сприяє підвищенню рівня фрізичного здоров'я, дозволяє дітям сформувати уявлення про правильну поставу і зменшити до мінімуму ризик розвитку ії порушень, $\epsilon$ ефективним у коригуванні нефіксованих порушень постави у дітей.

\section{Література}

1. Бароненко В. А. Здоровье и физическая культура студента : учеб. пособие / В. А. Бароненко, Л. А. Рапопорт; под ред. В. А. Бароненко. - М. : Альфа, 2003. - 352 с.

2. Башавець H. A. Історія розвитку проблеми збереження здоров'я молоді / Н. А. Башавець [Електронний ресурс] // Нар. освіта. 2009. - Вип. № 3 (9). - Режим доступу : http://www.narodna-osvita.kiev.ua/.

3. Богдан I. O. Карате WKF : навч. програма для дитячо-юнацьких спортивних шкіл / І. О. Богдан. - К. : Республік. наук.-метод. каб. М-ва молоді та спорту України, 2014. - 43 с.

4. Дунець-Лесько А. Аеробні та анаеробні можливості і рівень спеціальної підготовленості спортсменів-каратистів / А. Дунець-Лесько, Л. Вовканич, І. Богдан // Молода спорт. наука України. - 2011. - Т. 1. C. $80-86$.

5. Іванова А. $Є$. Фізичне виховання студентів з порушенням постави та сколіозами : навч.-метод. посіб. / А. Є. Іванова, Н. М. Ковальчук. Луцьк : Надстир'я, 2003. - 100 с.

6. Клапчук В. В. Кількісна оцінка рівня фізичного здоров'я та превентивна фізична реабілітація курсантів і студентів вищих навчальних закладів МВС України : навч. посіб. / В. В. Клапчук, В. В. Самошкін. - Дніпропетровськ : ЮАМВС, 2005. - 52 c.

7. Кошелев С. Вариации специальной физической подготовки учебно-тренировочного процесса по каратэ / С. Кошелев. - Оренбург Магна, 2004. -74 c.

8. Круцевич Т. Ю. Контроль в физическом воспитании детей, подростков и юношей : учеб. пособ. для студ. высш. учеб. заведений $/$ Т. Ю. Круцевич, М. И. Воробьев. - К. : НУФВСУ, 2005. - 195 с.

9. Мирная А. В. Динамика показателей системы крови у больных ревматоидным артритом в процессе курса реабилитации средствами каратэ / А. В. Мирная, Л. А. Шелест, Н.В.Маликов, Н. В. Богдановская // Педагогіка, психологія та мед.-біол. пробл. фіз. виховання і спорту: зб. наук. пр. за ред. С.С. Єрмакова. - Харків, 2009. - № 4. - С. 82-86.

10. Мирная А. В. Динамика показателей вариационной и амплитудной пульсометрии у больных ревматоидным артритом в процессе курса реабилитации средствами каратэ / А. В. Мирная, Н. В. Маликов // Педагогіка, психологія та мед.-біол. пробл. фіз. виховання і спорту : зб. наук. пр. за ред. С. С. Єрмакова. - Харків, 2008. - № 10. - С. 78-80.

11. Неділько В. П. Стан фізичного здоров'я дітей шкільного віку та шляхи його підвищення / В. П. Неділько, Т. М. Камінська, С. А. Руденко, Л. П. Пінчук // Перинатология и педиатрия. - 2009. - № 2. - С. 72-74.

12. Остьянов В. Н. Бокс (обучение и тренировка) : учеб. пособие / В. Н. Остьянов, И. И. Гайдамак. - К. : Олимп. лит., 2001. - 240 с.

13. Платонов В. Н. Общая теория подготовки спортсменов в олимпийском спорте / В. Н. Платонов. - К. : Олимп. лит., 1997. - 583 с.

14. Сисоєнко Н. Медико-гігієнічні проблеми збереження здоров'я дітей / Н. Сисоєнко // Шестирічки в школі. - К. : Ред. загальнопед. газ., 2004. - C. 35-36.

15. Tюx I. A. Факторний аналіз параметрів фізичного здоров'я дітей молодшого шкільного віку / І. А. Тюх // Молода спорт. наука України : зб. наук. ст. з галузі фіз. культури та спорту. - Л. : ЛДІФК, 2007. - С. 44.

16. Шиян Б. М. Теорія і методика фізичного виховання школярів: підруч. для студ. вищ. навч. закл. фріз. виховання і спорту / Б. М. Шиян. Т. : Навч. Кн., 2004. - 272 c.

\section{Перспективи подальших досліджень.}

Представлені в роботі матеріали з пошуку нових рекреаційних програм для підвищення рівня фрізичного здоров'я дітей та підлітків $\epsilon$ плановим науковим дослідженням кафедри спеціальної освіти та реабілітології Інституту управління і права Запорізького національного технічного університету, яке має бути продовжено.

\section{References}

1.Baronenko, V.A., \& Rapoport, L.A. (2003). Zdorovje i fizicheskaya kultura studenta [Health and physical education student]. V.A. Baronenko (Ed.). Moscow: Alpha [in Russian].

2. Bashavets, N.A. (2009). Istoriya rozvytku problemy zberezhennya zdorovya molodi [The history of the development problems of preservation of health of young people]. Narodna osvita - Folk education, Vip. 3 (9). Retrieved from http://www.narodna-osvita [in Ukrainian].

3. Bogdan, I.O. (2014). Karate WKF: navchalna programa dlya dityacho-yunatskykh sportyvnykh shkil [Karate WKF: training program for youth sports schools]. Kyiv: Respublikanskiy naukovometodichniy kabinet Ministerstva molodi ta sportu Ukraine [in Ukrainian].

4. Dunets-Lesko, A., Vovkanych, L., \& Bohdan, I. (2011). Aerobni ta anaerobni mozhlivosti i riven spechialnoyi pidgotovlenosti sportsmeniv-karatystiv [Aerobic and anaerobic possibilities and level of special preparedness of athletes-karatets]. Moloda sportivna nauka Ukraine - Young sports science of Ukraine, Vol. 1, 80-86 [in Ukrainian].

5. Ivanova, A.Ye., \& Kovalchuk, N.M. (2003). Fizychne vykhovannya studentiv z porushennyam postavy ta skoliozamy [Physical education of students with incorrect posture and scoliosis]. Lutsk: Nadstyrya [in Ukrainian].

6. Klapchuk, V.V., \& Samoshkin, V.V. (2005). Kilkisna otsinka rivnya fizychnoho zdorovya ta preventyvna fizychna reabilitatsiya kursantiv $i$ studentiv vyshchykh navchalnykh zakladiv MVS Ukrayiny [The Quantitative estimation of level of physical health and preventive physical rehabilitation students of higher educational institutions of the MIA of Ukraine]. Dnepropetrovsk: UAMVS [in Ukrainian].

7. Koshelev, S. (2004). Variatsii spetsialnoy fizicheskoy podgotovki uchebno-trenirovochnogo protsessa po karate [Variations of special physical preparation training process in karate]. Orenburg: Magna [in Russian].

8. Krucevich, T.Y,. \& Vorobev, M.I. (2005). Kontrol v fizicheskom vospitanii detey, podrostkov i junoshey [Control in physical education of children, adolescents and young adults]. Kiev: NUFVSU [in Russian].

9. Mirnaya, A.V., Shelest, L.A., Malikov, N.V., \& Bogdanovskaya, N.V. (2009). Dinamika pokazateley sistemi krovi u bolnish revmatoidnim artritom v prochesse kursa reabilitatsii sredstvamy karate [Dynamics of the parameters of the blood system in patients with rheumatoid arthritis in processes lo rehabilitation means karate]. S.S. Ermakov (Ed.). Kharkiv. Pedahohika, psykholohiya ta medyko-biolohichni problemy fizychnoho vykhovannya i sportu - Pedagogy, psychology and medical and biological problems of physical education and sport, 4, 82-86 [in Russian].

10. Mirnaya, A.V., \& Malikov, N.V. (2008). Dinamika pokazateley variatsionnoy i amplitudnoy pulsometrii u bolnish revmatoidnim artritom $v$ prochesse kursa reabilitacii sredstvamy karate [Dynamics of the parameters of variation and amplitude pulsometry in patients with rheumatoid arthritis during the course of rehabilitation means karate]. S.S. Ermakov (Ed.). Kharkiv. Pedahohika, psykholohiya ta medyko-biolohichni problemy fizychnoho vykhovannya i sportu - Pedagogy, psychology and medical and biological problems of physical education and sport, 10, 78-80 [in Russian]. 
17. Яцула М. С. Синдром шкільної дезадаптації: актуальність проблеми в першокласників / М. С. Яцула, С. Л. Нянковський // Педіатрія, акушерство та гінекологія. - 2008. - № 1. - С 17-19.
11. Nedilko, V.P., Kaminska, T.M., Rudenko, S.A., \& Pinchuk, L.P. (2009). Stan fizychnogo zdorovya ditey shkilnogo viku ta shlyachy jogo pidvyshchennya [The physical health of school-age children and ways of its improvement]. Perinatologiya i pediatriya - Perinatology and pediatrics, 2, 72-74 [in Ukrainian].

12. Ostyanov, V.N., \& Gaydamak, I.I. (2001). Box (obuchenie i trenirovka) [Boxing (training and coaching)]. Kiev: Olympiyskaja literatura [in Russian].

13. Platonov, V.N. (1997). Obshaja teorija podgotovki sportsmenov $v$ olimiyskom sporte [General theory of preparation of sportsmen in Olympic sport]. Kiev: Olympiyskaja literatura [in Russian].

14. Sysoyenko, N. (2004). Medyko-gigienichni problemy zberezhennya zdorovja ditey [Medical and hygienic problems of preservation of health of children]. Shestyrichky $v$ sholi - The six-year-olds in school. Kyiv: Red. zagalnopedagogich. gaz. [in Ukrainian].

15. Touch, I.A. (2007). Faktorniy analiz parametriv fizychogo zdorovja ditey molodshogo shkilnogo viku [Factor analysis of physical parameters of health of children of primary school age]. Moloda sportivna nauka Ukrainy - Young sports science of Ukraine. Lviv: LDIFC, 44 [in Ukrainian].

16. Shiyan, B.M. (2004). Teoriya i metodiyka fizychnogo vichovannya shkolyariv [Theory and methodology of physical education of schoolchildren]. Ternopil: Navchalna kniga [in Ukrainian].

17. Yatsula, M.S., \& Nyankovskyy S.L. (2008). Syndrom shkilnoyi dezadaptatsiyi: aktualnist problemy v pershoklasnykiv [Syndrome school exclusion: the relevance of the problem in children]. Pediatriya, akusherstvo ta hinekolohiya - Pediatrics, obstetrics and gynecology, 1, 17-19 [in Ukrainian].

Надійшла 27.02.2017 